ISSN (Online) 2710-3315

https://doi.org/10.20535/EHS.2021.232578

УДК 676.08

\title{
СУЧАСНІ ТЕХНОЛОГІЇ ПЕРЕРОБКИ ПЛАСТИКОВИХ ВІДХОДІВ В УКРАЇНІ
}

\author{
С.Ю. Існюк, Я.В. Радовенчик \\ Національний технічний університет України \\ «Київський політехнічний інститут ім. Ігоря Сікорського» \\ пр. Перемоги, 37, Київ, 03056, Україна \\ e-mail: sonechka4241@gmail.com
}

3 усіх різновидів відходів, зроблених людиною найбільшу небезпеку для навколишнього середовища становлять відходи різноманітних полімерів. Полімери розкладаються дуже повільно, вони самі та сполуки, що утворюються під час їхнього розкладання сильно забруднюють навколишнє середовище. Характерною рисою даного типу відходів є те, що вони стійкі до агресивних середовищ, процеси деструкції в природних умовах протікають досить повільно i, перш, ніж вони будуть становити інтерес для мікроорганізмів грунту, повинно пройти в середньому від 80 до 100 років.

В даний час проблема переробки відходів полімерних матеріалів стає вкрай актуальною 3 позиції охорони навколишнього середовища для більшості країн світу [1].

Протягом останніх років серйозною проблемою, яка привертає до себе все більше уваги, $\epsilon$ забруднення навколишнього середовища виробами із пластику. Пластик за своєю природою $\epsilon$ полімерним матеріалом. Природних полімерів, таких як каучук, існує багато, однак вони не впливають на забруднення та не несуть загрози для навколишнього середовища, оскільки вони не зберігаються протягом довгого часу в навколишньому середовищі та досить швидко розкладаються.

Сьогодні в Україні майже 96 \% усіх відходів, у тому числі пластик, відправляється на полігони, де роками продовжує "жити" у грунті. Наприклад, поліетиленовий пакет розкладається 500 років, звичайна пляшка з-під води - ціле тисячоліття.

На жаль, наша боротьба дуже часто залишається внутрішньою. Кожен ніби і розуміє, що є проблема, треба вирішувати, а коли настає час діяти - більшість просто залишається осторонь. У нас відсутня культура сортування сміття, а переробляється лише біля 7\% утворених побутових відходів. Це відбувається унаслідок відсутності налагодженої і розвиненої інфраструктури роздільного збирання, потужностей для переробки такого виду відходів, а ті, які існують, навіть недозавантажені: за технічної можливості переробляти 337 тис. тонн пластику переробляється лише не більше 180 тис. тонн [2, 3].

На сьогоднішній день існує три основних способи вторинної переробки полімерів. Першим $\epsilon$ термічний розклад за допомогою піролізу. В результаті піролізу утворюються напівфабрикати-мономери. Другий за популярністю спосіб пов'язаний 3 розкладанням матеріалу до рівня низькомолекулярних продуктів. Отримані продукти вторинної переробки можуть бути використані для виготовлення ливарних пластмас і легкорозчинних клеїв $[4,5]$. 
В Україні найбільшого поширення набув третій метод вторинної переробки полімерних матеріалів, який має назву механічний рециклінг, в результаті якого утворюється гранулят, придатний для вторинного виробництва пластмас.

Процедура рециклінгу пластикового сміття включає в себе наступні стадії:

- сортування та ідентифікація;

- $\quad$ подрібнення і дроблення;

- відмивання і сушка;

- $\quad$ агломерація або грануляція [3, 4].

Першим етапом переробки є поділ змішаних (побутових) відходів термопластів за видами. Його проводять наступними основними способами:

- $\quad$ флотаційним;

- повітряною сепарацією;

- електросепарацією;

- $\quad$ хімічними методами;

- методами глибокого охолодження.

Найбільшого поширення набув метод флотації, який дозволяє розділяти суміші таких промислових термопластів, як ПЕ, ПП, ПС і ПВХ.

Другий етап полягає в подрібненні полімерної сировини в крихту, розміри якої повинні складати від 10 до 30 міліметрів в залежності від матеріалу.

На третьому етапі відбувається відмивання і сушіння полімерної сировини. Цей етап найважливіший, так як від якості відмивання безпосередньо залежить якість готової продукції.

Четвертий етап - агломерація чи грануляція. Агломерація - це спікання відмитої крихти в невеликі грудки. Агломерат вже можна реалізовувати як вторинну сировину або гранулювати. При грануляції полімерна сировина стає більш однорідною, якісною і має велику насипну густину. Гранульовану сировину можна реалізувати за вищою вартістю [5].

Для сортування пластику розроблена міжнародна система маркування. Вона виглядає як трикутник, утворений стрілками 3 цифрою всередині (рис. 1). Під трикутником разом із цифрою або замість цифри може бути вказаний літерний код пластику.

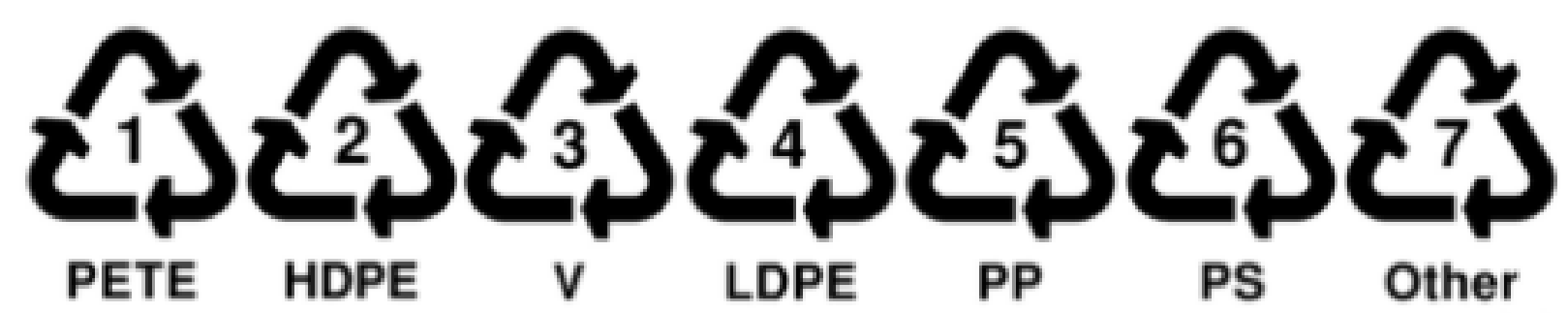

\section{Рисунок. Види пластику та його використання}

1 - поліетилентерефталат РЕТ (Е) або ПЕТ. Цей матеріал використовується для виготовлення одноразових пляшок для: води, газованої води і пива, косметичної продукції, молочних продуктів та рослинних олій, а також для упаковок. Він $є$ одним 3 найбільш безпечних видів пластику, який добре піддається переробці.

2 - поліетилен високого тиску PEHD (HDPE) або ПВТ. 3 цього матеріалу виготовляються пляшки та пакети для молока та води, флакони для шампунів, одноразовий посуд, контейнери 
для їжі, іграшки, господарські сумки та фасувальні пакети. Упаковка з такого типу пластику стійка до масел, кислот, лугів та до інших агресивних речовин.

3 - полівінілхлорид V (PVC) або ПВХ. Це основний матеріал для виробництва труб, садових меблів, віконних профілів, тари для миючих засобів, жалюзів. Також з цього матеріалу дуже часто виготовляють дитячі іграшки, красиві баночки під розсипні харчові продукти та пляшки під харчові жири (олії). Однак цей тип пластику не піддається переробці. При спалюванні полівінілхлориду утворюються високотоксичні хлорорганічні сполуки, а після десяти років служби вироби з ПВХ починають самостійно виділяти токсичні сполуки.

4 - поліетилен низького тиску LDPE (PELD) або ПНТ. ПТН застосовують для виробництва пакувальних матеріалів, пакетів для супермаркетів, виготовлення CD та DVD дисків, пляшок для миючих засобів. Вважається безпечним та придатним для харчових продуктів. Добре переробляється.

5 - поліпропілен РР або ПП. ПП використовують для виробництва склянок і баночок, медичної продукції, посуду для гарячих страв, пакувальної харчової плівки, контейнерів для продуктів, для сиропів та йогурту. Може виділяти формальдегід. Цей пластик має білий колір або напівпрозорі тони. Поліпропілен цінується за його термостійкість. Але він чутливий до світла та кисню, старіє швидше, ніж поліетилен. Піддається вторинній переробці.

6 - полістирол PS або ПС. Не зважаючи на те, що цей матеріал використовується для виробництва стаканів для гарячих напоїв (схожі на пінопласт), лотків для продуктів (схожі на пінопласт), стаканчиків для молочних продуктів, електроізоляційної плівки, контейнерів для їжі, виделок і ложок, фасувальних коробок для яєць, він вважається потенційно небезпечним, особливо у випадках горіння. Піддається вторинній переробці.

7 - полікарбонат та інші пластмаси OTHER (O) або IHШЕ. Такі типи пластику застосовують для виробництва посуду для їжі та води, багатошарової упаковки, комбінованого пластику. Це найнебезпечніший вид пластику при взаємодії з гарячими рідинами. В типі цього пластика має бути обов'язково вказано при якій температурі його можна використовувати. Якщо такої позначки немає, краще його не купляти. Цей тип пластика не піддається переробці [1,2].

Перероблена пластикова пляшка може повернутися в побут в незвичайних образах. Наприклад, Флекс (вторинну гранулу) використовують для створення хімічного волокна, яке, потім використовується при виробництві щетини для щіток в збиральних машинах, автомийках, при виготовленні пакувальної стрічки, плівки, черепиці та навіть тротуарної плитки.

Також Флекс широко використовується у швейній промисловості у вигляді нетканих матеріалів, які утеплюють інші тканини і надають їм міцність, наприклад флізелін. Крім цього, вироблена з ПЕТ тканина - поліестер, використовується при виготовленні повсякденного одягу [1].

Полімерні побутові відходи можуть бути використані як один з основних компонентів у виробництві різноманітних будівельних матеріалів: будівельних композицій, гідроізоляційних матеріалів, дорожніх покрить, тощо.

Таким чином, застосування у виробництві вторинної полімерної сировини дозволяє знизити собівартість продукції, не знижуючи а іiі споживчі властивості, також вирішує проблему шкідливого впливу відходів пластмас на навколишнє середовище. Завдяки переробці вторинної сировини із пластику зберігаються природні ресурси, економиться витрата нафти, з якої спочатку проводиться полімер, скорочується обсяг відходів і знижуються викиди діоксиду вуглецю.

\footnotetext{
Handbook of the XXII International Science Conference «Ecology. Human. Society» (2021 Kyiv, Ukraine)
} 
Вторинна переробка пластика дозволяє отримати сировину, яка практично не поступається за своїми властивостями пластику, виготовленому з первинного ПЕТ. Відібраний пластиковий матеріал проходить спеціальні цикли по обробці та очистці, завдяки чому він може бути використаний велику кількість разів, при цьому пластик не втрачає своїх основних властивостей [4].

Проблема пластикових відходів не вирішиться без спрямованої державної політики, тому уряду потрібно заборонити безкоштовне розповсюдження поліетиленових пакетів у супермаркетах та запровадити відповідні санкції у разі порушення. Також доцільно булоб перейняти досвід інших країн щодо поступової повної відмови від деяких полімерних матеріалів.

Міським адміністраціям та об’єднаним територіальним громадам на базі регіональних планів необхідно почати створювати важливі інфраструктурні об'єкти для збирання, сортування, транспортування та переробки сміття, як того вимагає Українське законодавство. А громадяни мають почати вирішувати дану проблему 3 власної домівки, елементарно скоротивши використання пластику у повсякденному житті. Почати збирати та сортувати відходи, мобілізуватися та активно приймати участь у подібних громадських проектах та ініціативах. Лише спільними зусиллями Україна може попередити екологічну катастрофу тотального пластикового забруднення.

\section{Література:}

1. Сафранов Т. А. Управління та поводження з відходами / Т. А. Сафранов, М. О. Клименко. - Одеса: Міністерство освіти і науки, молоді та спорту Укр., 2012. - 259 с.

2. Поводження з відходами [Електронний ресурс]. - 2016. - Режим доступу до ресурсу: http://solvetpv.lviv.ua/poznachky-na-plastyku-shho-potribno-znaty-koly-vy-kupuyete-vodu-vplastykovij-plyashtsi/.

3. Домашній бізнес в Україні. Переробка пластикових відходів - надприбуткова ідея [Електронний ресурс] / Домашній бізнес в Україні - Режим доступу до ресурсу: https://homebiznes.in.ua/biznes-na-pererobtsi-plastykovyh-vidhodiv-nadprybutkova-ideya/.

4. Бригінець К. Д. Утилізація промислових відходів. Основи утилізації відходів: конспект/ К. Д. Бригінець, К. О. Абашина; Харк. нац. акад. міськ. госп-ва., - Х.: ХНАМГ, 2012. - 58 с.

5. Чобан А.Ф. Утилізація та рекуперація відходів. Метод. Посібник. - Чернівці: Рута, 2008. $-98 \mathrm{c}$. 